\title{
First report of Eimeria sardinae (Apicomplexa: Coccidia) from the Turkish coast of the Black Sea
}

\section{Eimeria sardinae (Apicomplexa: Coccidia) türü parazitin Karadeniz’in Türkiye kıyısından ilk bildirimi}

\author{
Ahmet Özer ${ }^{\text {^* }}$ - Türkay Öztürk1 • Violetta Yurakhno² • Yulia M. Kornyychuk² \\ ${ }^{1}$ Sinop University, Faculty of Fisheries and Aquatic Sciences, 57000 Sinop, Turkey \\ 2Institute of Biology of the Southern Seas, 2 Nakhimov Av., Sevastopol 299011, Russia \\ *Corresponding author: aozer@sinop.edu.tr
}

\section{How to cite this paper:}

Özer, A., Öztürk, T., Yurakhno, V., Kornyychuck, M.Y.,2014. First report of Eimeria sardinae (Apicomplexa: Coccidia) from the Turkish coast of the Black Sea. Ege J Fish Aqua Sci, 31(3): 151-153. doi: 10.12714/egejfas.2014.31.3.06

\begin{abstract}
Özet: Karadeniz'in Sinop kıylarından Mayıs 2011 - Mayıs 2013 tarihleri arasında yakalanan mezgit balığııı, Merlangius merlangus L., 1758, parazitleri araşıııılı ve incelenen 530 adet balıktan Mart 2012 tarihinde yakalanan 1 adedinin barsak içeriğinde çok sayıda Eimeria sardinae (Thélohan, 1890) Reichenow, 1921 ookistinin varlığı belirlendi. Bu parazit türü ne Karadeniz'in Türkiye kıyılarında ne de mezgit balığında daha önce bildirilmedi. Dolayısıyla bu tür Türkiye parazit faunası için yeni bir kayıttır, fakat mezgit balığı bu tür için gerçek bir konak olmayabilir. Mezgit balığının bağırsak içeriğinde bulunan $E$. sardinae ookistleri bu parazitin konağı olduğu bilinen ve mezgit balığının doğal besinini oluşturan Sprattus sprattus ya da Engraulis encrasicolus gibi avlar ile alınmış olabilir.
\end{abstract}

Anahtar kelimeler: Eimeria sardinae, Merlangius merlangus, Sprattus sprattus, Engraulis encrasicolus, Karadeniz

Abstract: Whiting Merlangius merlangus L., 1758 collected from the Black Sea coasts of Sinop, Turkey, during May 2011 - May 2013 period were examined for parasites and one of 530 examined fish specimens caught in March 2012 had numerous oocysts of Eimeria sardinae (Thélohan, 1890) Reichenow, 1921 in its intestinal content. The parasite has not been reported previously from the Turkish Black Sea coasts as well as from this fish. Hence this is a new record for the Turkish parasite fauna. Nevertheless, whiting might not be a true host of this parasite. E. sardinae oocysts found in the intestine content of whiting might have come from natural preys such as Sprattus sprattus or Engraulis encrasicolus that are known host of this parasite.

Keywords: Eimeria sardinae, Merlangius merlangus, Sprattus sprattus, Engraulis encrasicolus, Black Sea

\section{INTRODUCTION}

Eimeria sardinae (Thélohan, 1890) Reichenow, 1921 (syn.: Coccidium sardinae Thélohan, 1890, Eimeria oxyphila Dobell, 1919, E. oxyspora Dobell, 1919, E. patagonensis Timi and Sardella, 1998, E. snijdersi Dobell, 1920 and Eimeria sp. of Morrison and Marryatt, 1990) is a cosmopolitan coccidian has been reported from Clupeiformes, including twaite shad Alosa fallax, Pacific herring Clupea harengus, European anchovy Engraulis engrasicolus, European pilchard Sardina pilchardus, Spanish sardine Sardinella aurita and Madeiran sardine S. maderensis, South African sardine Sardinops sagax and European sprat Sprattus sprattus living in Atlantic and Pacific Oceans, Mediterranean Sea, Black Sea, Adriatic Sea, North Sea, Barent Sea, White Sea and it has been found only in male gonads (Pellerdy, 1965; Daoudi et al., 1989; Morrisson, 1991; Diouf, 1993; Diouf and Toguebaye, 1994; Tolonen and Karsbakk, 2003; Yurakhno and Gaevskaya, 2004; Reed et al., 2011). However, Dragoui et al., (1995) reported several developmental stages of this parasite in both male and female gonads of Sardinella aurita and Sardina pilchardus near Tunisian shores. In the present study, a survey was conducted to determine the parasites of whiting from the Sinop coast of the Black Sea.

\section{MATERIALS AND METHODS}

During parasitological survey of 530 whiting, Merlangius merlangus L., 1758, specimens were collected by commercial fishermen from the Black Sea around Sinop Province in Turkey between May 2011 and May 2013. Common parasitological methods were used to examine all internal organs, including intestine. For this purpose, smears were prepared from all tissues and examined under a light microscope (Olympus BX51) by using phase-contrast. Whenever necessary, photographs were taken by DP-25 digital camera using data-processing software DP2-BSW 


\section{RESULTS}

Out of 530 fish specimens examined, numerous coccidian oocysts (Figure $1 \mathrm{~A}$ ) were observed only in the intestinal smears of one female whiting (with a total length of $15.0 \mathrm{~cm}$ and weight of $19.6 \mathrm{gr}$ ) caught in March 2012. Oocysts were spherical and varied in size, from $41.4 \mu \mathrm{m}$ to $42.9 \mu \mathrm{m}$ (Figure $1 \mathrm{~B})$; the sporocysts were fusiform, sharply pointed and measured 26,9 to $29.5 \mu \mathrm{m}$ by $3.5-4.0 \mu \mathrm{m}$ (Figure $1 \mathrm{C}$ ). Observed coccidians were identified as Eimeria sardinae according to methodology provided by Lom and Dykova (1992).
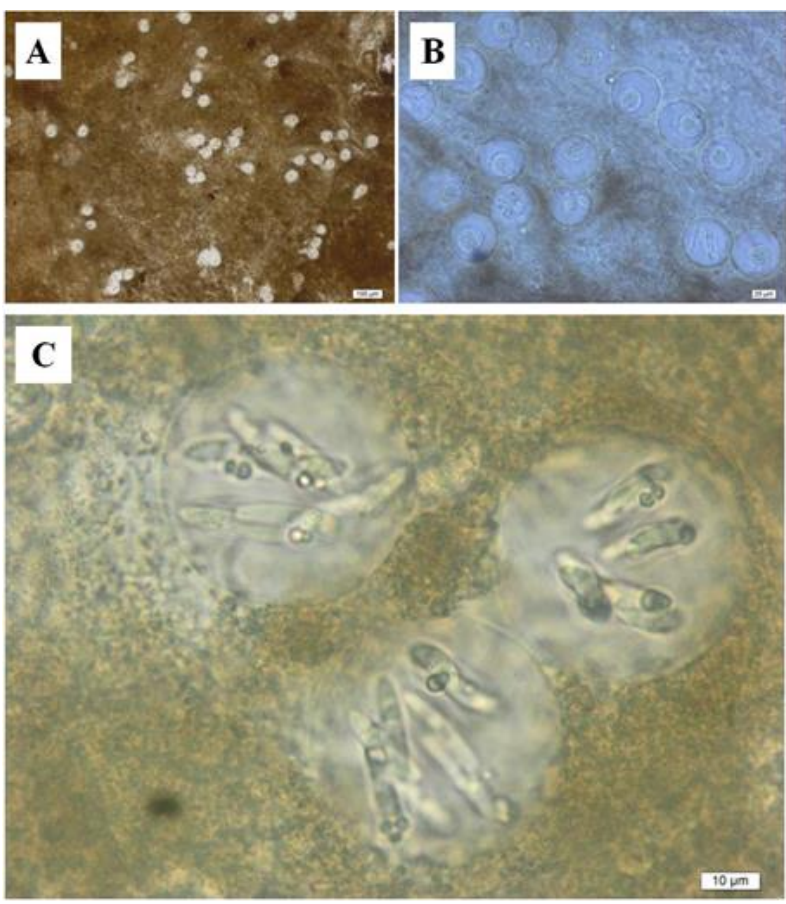

Figure 1. Eimeria sardinae oocysts and sporozoites. A. Numerous oocyts in intestinal smear of whiting, B. Developing sporozoites in oocysts, C. Mature sporozoites in oocytes.

\section{DISCUSSION}

A fish survey near Crimean Black Sea coast had shown that E. sardinae used Sprattus sprattus and Engraulis encrasicolus as hosts and it infests only the gonads of male

\section{REFERENCES}

Daoudi, F., Radujkovic, B.M., Marques, A., Bouix, G., 1989. Parasites des poissons marins du Montenegro: Coccidies. Acta Adriatica, 30: 13-30.

Diouf, J.N., 1993. Etude taxonomique, ultrastructurale et biologiquedes Coccidies (Protozoaires, Apicomplexes) parasites de poissons des cotes senegalaises. Ph.D. Thesis, University of Cheikh Anta Diop, Senegal.

Diouf, J.N., Toguebaye, B.S., 1994. Eimeria sardinae Reichenow, 1921 (Apicomplexa, Coccidia) infection in Sardinella maderensis (Lowe, 1839) (Clupeidae) from the Senegal coast. Bulletin of European Association for Fish Pathologists, 14: 41-43.

Dogel, V.A., 1940. Coccidia from testis of Clupeidae (In Russian). Trudy Liningradskogo Obschestva Estestvoispytateley, 48: 32 - 38. fish (Dogel, 1940; Pogoreltseva, 1964; Gaevskaya et al., 1975; Yurakhno and Gaevskaya, 2004). The most intensive sporulation of $E$. sardinae occurs during postspawning period of sprat (from May to September) when fish testes exempt from most of the sperm. This suggests a balanced hostparasite relationship in the system of "sprat - Eimeria sardinae". As $E$. sardinae prevalence in sprat population near Crimean Black Sea coasts ranged from 23 to $80 \%$ and significantly varied in investigated sprat stocks, this parasite believed to be suitable biomarker for identification of local sprat stocks (Yurakhno and Gaevskaya, 2004; Kornyychuk et al., 2007).

Morrison and Hawkins (1984) reported E. sardinae infesting host fish up to $90-100 \%$ and in heavy infestations as much as $19 \%$ of testis was found to be replaced by the parasite agglomerations. In those fish, spermatic cords were found to be distorted but still distinguishable and replacement of testicular tissue by $E$. sardinae reduced sperm production, thus detrimentally affected Clupea harengus stocks. It may also cause testes atrophy and reduce male fecundity where developed intensively in Sardinella maderensis (Diouf and Toguebaye, 1994). So, this parasite species has a potential for pathology and detrimental effects on fish host stocks. It could also be noted that $E$. sardinae infections in sprat and anchovy might be a factor influencing negatively the fecundity of $S$. sprattus or $E$. encrasicolus males, thus a research study to evaluate this assumption should be warranted - as well as using this parasite as a biomarker for the identification of local sprat and anchovy stocks around the Turkish coasts.

Our data and observations have led us to conclude that Eimeria sardinae oocytes present in the intestine of whiting due to ingestion of European sprat or European anchovy as food fish; so, M. merlangus is not a true host for the oocysts. Nevertheless, $E$. sardinae is a new parasite record for Turkish fauna.

\section{ACKNOWLEDGEMENTS}

This study was supported financially by Turkish Scientific and Technological Council (TÜBITAK) in Turkey and National Academy of Sciences of Ukraine (NASU) with the project number 1100475. Authors are grateful to this support.

Dragoui, N., Coste, F., Marques, A., Romestand, B., Maamouri, F., Bouix, G., 1995. Presence of Eimeria sardinae Reichenow, 1921 in male and female specimens of Sardina pilchardus Regan, 1916 and of Sardinella aurita Valenciennes, 1847 from the Tunisian shores. Bulletin of European Association for Fish Pathologists, 15: 84-87.

Gaevskaya, A.V., Gusev, A.V., Delyamure, S.L., Donets, Z.S., Iskova, N.I., Kornyushin, V.V., Kovaleva, A.A., Margaritov, N.M., Markevich, A.P., Mordvinova, T.N., Naidenova, N.N., Nikolaeva, V.M., Parukhin, A.M., Pogoreltseva, T.P., Smogorzhevskaya, L.A., Solonchenko, A.I., Shtein, G.A., Shulman, S. S., 1975. Opredelitel' parazitov pozvonochnyh Chernogo i Azovskogo moreyb (In Russian). - Kiev: Nauka dumka, 552 p.

Kornyychuk, Y.M., Yurakhno, V.M., Zavyalov, A.V., 2007. Regional differences of infection by core parasite species of sprat Sprattus 
sprattus phalericus, inhabiting at the Black Sea coast of Crimea (In Russian). Rybne Gospod Ukraini, 1/2: 32 - 35.

Lom, J., Dykova, I., 1992. Protozoan parasites of fishes. Elsevier, The Nederlands

Morrisson, C.M., 1991. Further observations on the sporogony of Eimeria sardinae in Clupea harengus L. Canadian Journal of Zoology, 69: 10171024. doi: 10.1139/z91-147

Morrisson, C.M., Hawkins, 1984. Coccidians in the liver and testes of the herring Clupea harengus L. Canadian Journal of Zoology, 62: 480-493. doi: 10.1139/z84-073

Pellerdy, L.P., 1965. Coccidia and coccidiosis. Akademiai kiado, Hungary

Pogoreltseva, T.P., 1964. Materials for the study of parasitic protozoa of the Black Sea fish (In Russian). Problemy parasitologii: Trudy ukrainskogo respublikanskogo obschestva parasitologov. Nauka dumka, Kiev, pp. 16 $-29$.

Reed, C.C., MacKenzie, K., van der Lingen, C.D., 2011. Parasites as biological tags for South African Sardines (Abstract only). VIII. International Symposium of Fish Parasites, 26-30 September 2011, Chile.

Tolonen, A., Karsbakk, E., 2003. The parasite fauna of the Norwegian spring spawning herring (Clupea harengus L.). ICES Journal of Marine Sciences, 60: 77-84. doi: 10.1006/jmsc.2002.1307

Yurakhno, V.M., Gaevskaya, A.V., 2004. On the Black Sea sprat, Sprattus sprattus phalericus, infestation with a coccidian Eimeria sardinae (Coccidiida, Eimeriidae) (In Russian).Vestnik Zoology, 18: 176-179. 